\title{
Effect of Harvest Period on the Quality of storage roots and protein content of the leaves in five cassava cultivars (Manihot esculenta, Crantz)
}

\author{
Edvaldo Sagrilo $^{1}$, Pedro Soares Vidigal Filho ${ }^{2 *}$, Manoel Genildo Pequeno ${ }^{2}$, Carlos Alberto \\ Scapim $^{2}$, Maria Celeste Gonçalves Vidigal ${ }^{2}$, Sérgio Paulo Severo de Souza Diniz ${ }^{3}$, Elisa \\ Cristina Modesto ${ }^{4}$ and Marcus Vinícius Kvitschal ${ }^{2}$ \\ ${ }^{1}$ Brazilian Agricultural Research Corporation; Av. Duque de Caxias, 5650; CEP 64006-220; Teresina - PI - Brazil. \\ ${ }^{2}$ Agronomy Department, Maringá State University; Av. Colombo, 5790; CEP 87020-570; Maringá - PR. - Brazil. \\ 3 Biochemistry Department, Maringá State University; Av. Colombo, 5790; CEP 87020-570; Maringá - PR. - \\ Brazil. ${ }^{4}$ Zootecny Department, Maringá State University; Av. Colombo, 5790; CEP 87020-570; Maringá - PR. - \\ Brazil
}

\begin{abstract}
The effect of harvest period on the quality of storage roots and leaves of cassava cultivars was determined in an experiment carried out in a randomized complete block design with four replications in a split plot scheme, with five cultivars in the plots and ten harvest times in the subplots. The IAC 13 cultivar had the highest rate of dry matter accumulation in the storage roots and the Mico cultivar the lowest. The period of least dry matter content in the storage roots occurred later for the Fécula Branca, Mico and IAC 14 cultivars, and the minimum starch content in the storage roots occurred later for the Fécula Branca and Mico cultivars. In general, the IAC 13, IAC 14 and Fécula Branca cultivars had higher dry matter content in the storage roots, while higher starch content in the dry and fresh matter were obtained in the Fécula Branca cultivar. The crude protein content in the leaves decreased as the plant aged.
\end{abstract}

Key words: Harvest period; cultivars; dry matter content; starch content; leaf protein

\section{INTRODUCTION}

Cassava is one of the energetic bases in the nutrition of the low income population in tropical and subtropical countries (Carvalho et al., 1993a), and is the food basis for approximately 500 million people throughout the world (Cassava, 2000). Also being used in animal meal and as raw material for various industrialized products (Doretto, 1993).
Cassava plant is cultivated mainly for its storage roots (Ravindran, 1993), and it produces potentially more calories per area unit than any other crop in the world except sugar cane (Cassava, 2000). Energy production from the cassava crop is $250 \times 10^{3}$ cal.ha $^{-1}$. day ${ }^{-1}$, compared with $200 \times 10^{3}, 176 \times 10^{3}, 114 \times 10^{3}$ e $110 \times 10^{3}$ cal.ha $^{-1}$.day ${ }^{-1}$, produced by maize, rice, sorghum and wheat, respectively (Balagopalan et al., 1988). However, besides the storage roots being rich in starch, the cassava plant canopy has gained

* Author for correspondence 
importance because it might be a source of proteins, vitamins and minerals for human and animal nutrition (Carvalho et al., 1985; Carvalho et al., 1993a). Among the reasons for these speculations is the fact that the leaf protein content is high for a non-leguminous crop, being on average around $210.0 \mathrm{~g} \cdot \mathrm{kg}^{-1}$ (Ravindran, 1993) although values vary from $147.0 \mathrm{~g} \cdot \mathrm{kg}^{-1}$ to 400.0 g. $\mathrm{kg}^{-1}$ in dry matter. The variations have been attributed to several factors, both in the dry matter and starch content in the roots and the cassava leaf protein content, but the most important are those which refer to differences among cultivars, as well as the harvesting period of the storage roots (Jesus et al., 1986; Fukuda and Borges, 1990) and of the canopy (Carvalho et al., 1985; Ravindran, 1993). Thus studies are needed to establish the most suitable crop stage for harvest by regions and by cultivar that would provide highly nutritious foliage (Carvalho et al., 1991) and storage roots with high dry matter and starch contents (Wholey and Booth, 1979).

Therefore, this study was carried out to determine the effect of different harvest periods on the storage root and leaves quality of five cassava cultivars in the Northwest of Paraná State, Brazil.

\section{MATERIALS AND METHODS}

The experiment was carried out from October 1997 to May 1999 in Araruna, Northwest of Paraná State, in a distrophic red lattosoil (Embrapa, 1999).

The chemical analysis of soil samples from the experimental area, in the $0-0.20 \mathrm{~m}$ deep layer, performed before setting up the experiment, showed that it had the following composition: $\mathrm{pH}$ $\left(\mathrm{CaCl}_{2}\right), 5.2 ; \mathrm{pH}$ (water), 6.4; $\mathrm{Al}^{3+}\left(\mathrm{cmol}_{\mathrm{c}} \cdot \mathrm{dm}^{-3}\right)$, $0.00 ; \mathrm{H}^{+}+\mathrm{Al}^{3+}\left(\mathrm{cmol}_{\mathrm{c}} \cdot \mathrm{dm}^{-3}\right), 3.17 ; \mathrm{Ca}^{2+}+\mathrm{Mg}^{2+}$ $\left(\mathrm{cmol}_{\mathrm{C}} \cdot \mathrm{dm}^{-3}\right), 2.44 ; \mathrm{Ca}^{2+}\left(\mathrm{cmol}_{\mathrm{c}} \cdot \mathrm{dm}^{-3}\right), 1.49 ; \mathrm{K}^{+}$ $\left(\mathrm{cmol}_{\mathrm{c}} \cdot \mathrm{dm}^{-3}\right), 0.32 ; \mathrm{P}\left(\mathrm{mg} . \mathrm{dm}^{-3}\right), 5.0 ; \mathrm{C}\left(\mathrm{g} \cdot \mathrm{dm}^{-3}\right)$, 13.57. The climate in Araruna is the Cfb type according to the Köppen classification, with $21.5^{\circ} \mathrm{C}$ mean annual temperature, $1,617 \mathrm{~mm}$ mean annual rainfall and $62 \%$ mean annual relative humidity (Godoy et al., 1976). Fig. 1 shows the climatic data recorded in the experimental period.

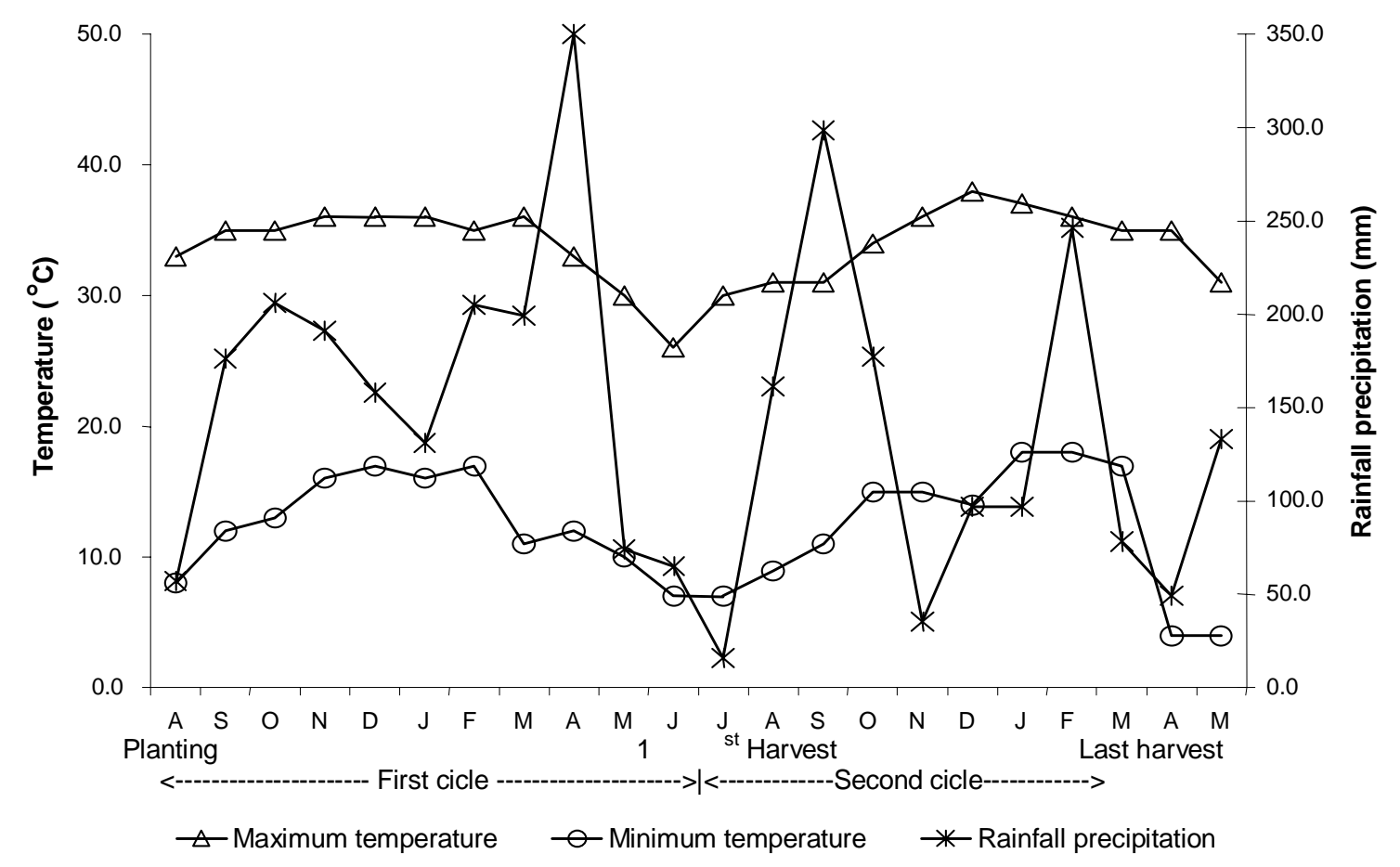

Figure 1 - Mean monthly rainfall precipitation and maximum and minimum temperatures observed from August 1997 to May 1999 in Araruna, PR. 
The Mico, Fibra, IAC 13, IAC 14 and Fécula Branca cassava cultivars were harvested for evaluation at ten different times during the second plant cycle. They were defined as suitable for cultivation in the region by Vidigal Filho et al. (2000). A randomized complete block design with four replications and treatments arranged in split plots was used. The cultivars were randomly distributed in plots (main treatments) and the harvest times in the sub-plots (secondary treatments).

The plot dimensions were $17.6 \mathrm{~m}$ (length) x 22.0 $\mathrm{m}$ (width), with $1.0 \mathrm{~m}$ spacing between rows and $0.80 \mathrm{~m}$ among plants in the same row. The total area of each plot was $327.2 \mathrm{~m}^{2}$, with each of the 10 subdivisions (sub-plots) referring to a harvest time. Each sub-plot was composed of a row of 22 plants, with intercalated individual side borders. The plants at the extremities of each sub-plot that formed the row end borders were also discarded. The useful area of each sub-plot was $16.0 \mathrm{~m}^{2}$ from which six plants were randomly harvested for data collection (Veltkamp, 1985).

Plants were collected monthly starting at 12 months of age and $60 \mathrm{~g}$ samples were taken from both, storage roots and fresh leaves. The storage roots were sliced and cut in cubes of approximately $0.01 \mathrm{~m}$ and dried at $60^{\circ} \mathrm{C}$ in a forced air dryer until constant weight, to determine their respective dry matter content (Sales Filho, 1980). The leaves were dried at $45^{\circ} \mathrm{C}$ to obtain the dry matter (Silva, 1981). The dry matter (storage roots and leaves) was ground in a Wiley-Thomas type grinder with a 60 mesh sieve and placed in Wheaton tubes until the subsequent analyses. The following characteristics were assessed:

a) dry matter content in the storage roots (DMR): Mean value expressed in $\mathrm{g} . \mathrm{kg}^{-1}$ obtained after weighing on semi-analytical scales, cubes of approximately $0.01 \mathrm{~m}^{2}$ of storage roots dried in a forced air dryer;

b) starch content based on dry matter (SDM): Mean value expressed in g. $\mathrm{kg}^{-1}$ obtained by the Iodine method followed turbidimetrically at 610 $\mathrm{nm}$ by the strong blue chromophere formed (Diniz, 1999);

c) starch content based on the fresh matter (SFM): Mean value expressed in $\mathrm{g}_{\mathrm{kg}}{ }^{-1}$ was obtained by the following equation:

$$
S F M=\frac{S D M \times D M R}{1000} ;
$$

d) Crude leaf protein content (PTN): Mean value expressed in g. $\mathrm{kg}^{-1}$ obtained by determining the total nitrogen using the Kjeldahl method, according to AOAC (1970) from ground leaf dry matter samples.

The data were submitted to analysis of variance. The cultivars means were compared by the Tukey test at $5 \%$ of probability $(\mathrm{P} \leq 0.05)$, while the harvest time means were analyzed by polynomial equation models, according to Banzatto and Kronka (1995).

\section{RESULTS AND DISCUSSION}

Analysis of variance of the data for dry matter and starch content in the storage roots and crude leaf protein content showed significant $(\mathrm{P} \leq 0.05)$ cultivar and harvest time main effects and cultivar $\mathrm{x}$ harvest time interaction for all the assessed characteristics. Consequently, individual mathematical models were fitted to each cultivar to explain the biological phenomena that affected the cassava plant performance along the harvesting period.

The variations observed in the storage roots dry matter content for all the cultivars during the harvest times allowed the fitting of cubic order polynomial models (Fig. 2). Such behavior was characterized by high values for the first harvest, which decreased rapidly in the subsequent harvests. Fig. 2 shows that the Fibra and IAC 13 cultivars had minimum points at 14.80 (308.55 g.kg $\left.{ }^{-1}\right)$ and 14.67 (326.87 g. $\left.\mathrm{kg}^{-1}\right)$ months, respectively, while Mico, IAC 14 and Fécula Branca had respective minimum points occurring later, at $15.78\left(256.50{\mathrm{~g} . \mathrm{kg}^{-1}}^{-1}\right), 15.34(336.25$ g. $\mathrm{kg}^{-1}$ ) and 15.63 (336.38 g. $\left.\mathrm{kg}^{-1}\right)$ months. A new stage of root dry matter accumulation was observed starting in this period until the tenth harvest time, when the curve tended to stabilize again.

Some striking differences in cultivar behavior were detected especially for the Mico cultivar, which had high means in the first harvest but showed a significant fall in the storage root dry matter content when compared to the other cultivars. IAC 13 had a higher accumulation rate of storage root dry matter than the other cultivars at the end of the harvest.

The variations in the storage root dry matter contents over the harvest times followed a 
seasonal pattern (Hammer et al., 1987; Hobman et al., 1987) and were higher in slow growing and plant rest and decreased sharply during the canopy regeneration and active growth periods.

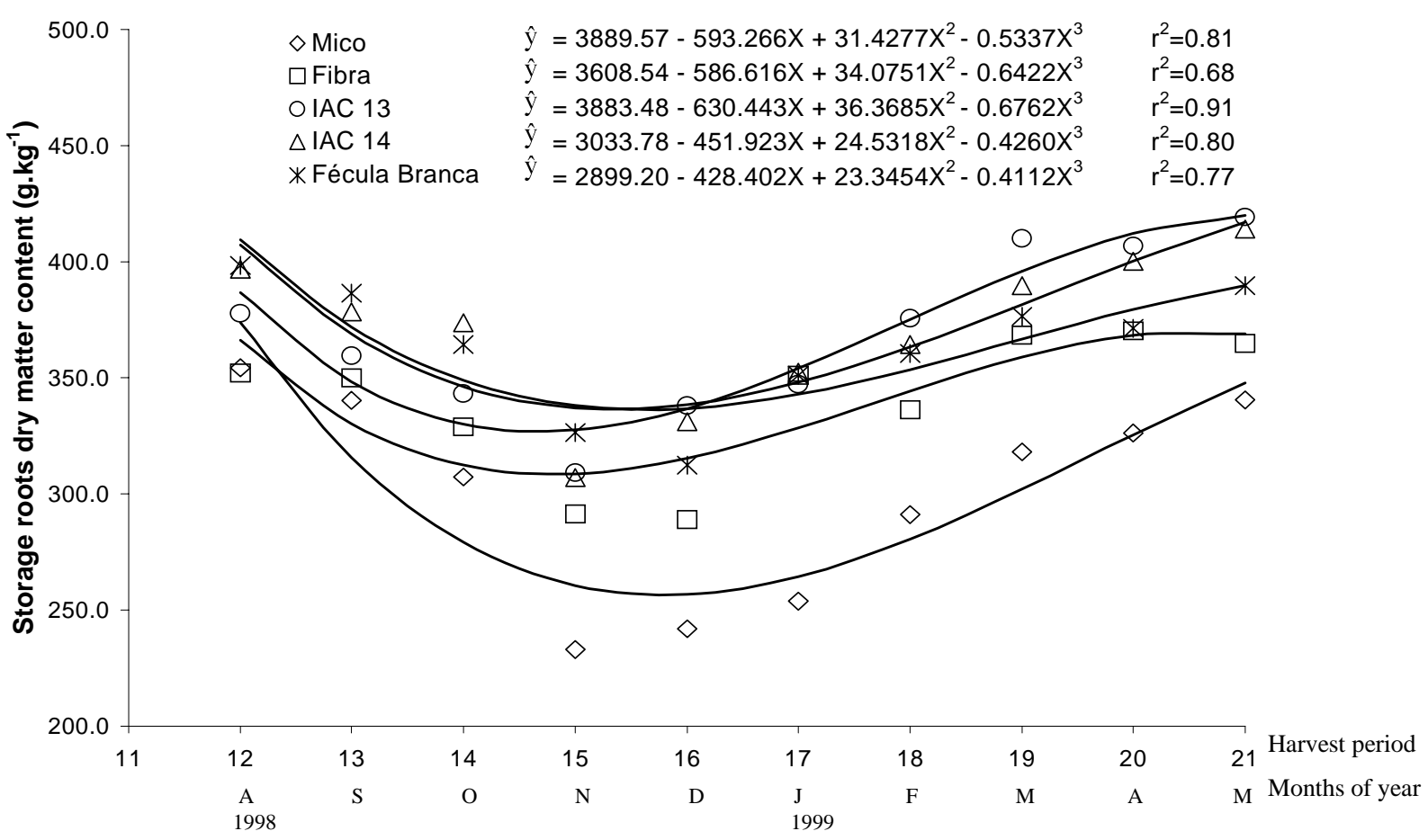

Figure 2 - Storage roots dry matter content $\left(\mathrm{g}_{\mathrm{kg}} \mathrm{kg}^{-1}\right)$ of five cassava cultivars to 10 harvest times during the second plant cycle (Araruna-PR 2001).

Thus the high contents observed in the first harvest were based on the fact that the plants were at the end of the first physiological rest period, while the subsequent reduction in these values was probably caused by the need to mobilize starch from the storage roots to meet the demand of new forming plant structures (Sales Filho, 1980). The full architectural re-structuring of the plant foliage in the second plant cycle, associated with the occurrence of high rainfall, as well as appropriate temperatures to cassava plant photosynthesis (Fig. 1) that is, $25^{\circ} \mathrm{C}$ to $35^{\circ} \mathrm{C}$ (El-Sharkawy et al., 1984), lead the plants to a new period of dry matter accumulation in the storage roots which might have been due to a positive balance in the photoassimilates produced. According to Keating et al. (1982), the physiological rest period represented the best harvest time, because of the high storage root production and their high contents of dry matter.

There were also significant differences among the cultivars (Table 1) at all the harvest times. In general, higher means were obtained with the IAC
14, IAC 13 and Fécula Branca cultivars at all the times assessed but these cultivars did not differ from the Fibra cultivar at 13, 15, 17 and 20 months.

The Mico cultivar showed the least means in all the harvests, but did not differ from the Fibra cultivar at 12, 13, 14 and 21 months. The superiority of the IAC 14, IAC 13 and Fécula Branca for dry matter content present in the storage roots was also observed by Vidigal Filho et al. (2000) in plants with one plant cycle, when compared with Fibra and Mico. Therefore, the differences are evident among cultivars for the dry matter content present in the storage roots and the importance of selecting materials which have high content, to obtain greater agro-industrial yield.

The statistical significance of the cultivar $\mathrm{x}$ harvest time interaction for starch content based on the storage root dry matter enabled the adjustment of polynomial equations of quadratic order for all assessed cultivars. Fig. 3 shows that the starch content in the storage roots dry matter was high at the beginning of the harvest time but decreased in 
the following months, with the minimum points occurring at 15.87 months for Mico (565.63 g.kg-1 $), 15.98$ months for Fibra $\left(564.17\right.$ g. $\left.\mathrm{kg}^{-1}\right)$, 15.63 months for IAC $13\left(545.37 \mathrm{~g} . \mathrm{kg}^{-1}\right), 15.66$ months for IAC 14 (550.70 g. $\left.\mathrm{kg}^{-1}\right)$ and 15.67 months for Fécula Branca $\left(619.25\right.$ g.kg $\left.{ }^{-1}\right)$.

The minimum value obtained for Fécula Branca was on average $11.32 \%$ superior to the respective minimum values obtained for the other cultivars.

Table 1 - Means of storage roots dry matter content $\left(\mathrm{g} \cdot \mathrm{kg}^{-1}\right)$ of five cassava cultivars at 10 harvest times during the second plant cycle (Araruna-PR 2001) (means of four replicates)

\begin{tabular}{|c|c|c|c|c|c|c|c|c|c|c|}
\hline \multirow[b]{3}{*}{ Cultivars } & \multicolumn{10}{|c|}{ Storage roots dry matter content $\left({\left.\mathrm{g} . \mathrm{kg}^{-1}\right)}^{-1}\right.$} \\
\hline & \multicolumn{10}{|c|}{ Harvest period } \\
\hline & 12 (Aug) & 13 (Sep) & 14 (Oct) & 15 (Nov) & $16(\mathrm{Dec})$ & 17 (Jan) & $18(\mathrm{Feb})$ & 19 (Mar) & 20 (Apr) & 21 (May) \\
\hline Mico & $354.4 \mathrm{~b}$ & $340.2 \mathrm{~b}$ & $307.2 \mathrm{c}$ & $232.9 \mathrm{~b}$ & $241.9 \mathrm{c}$ & $253.8 \mathrm{~b}$ & 291.1 & $318.2 \mathrm{c}$ & $326.1 \mathrm{~b}$ & 340.5 \\
\hline Fibra & $352.1 \mathrm{~b}$ & $350.0 \mathrm{ab}$ & $328.9 \mathrm{bc}$ & $291.3 \mathrm{a}$ & 288.9 b & $351.0 \mathrm{a}$ & $336.3 \mathrm{~b}$ & $368.3 \mathrm{~b}$ & $370.4 \mathrm{a}$ & $364.8 \mathrm{bc}$ \\
\hline IAC 14 & $396.8 \mathrm{a}$ & $378.5 \mathrm{a}$ & $373.9 \mathrm{a}$ & $307.0 \mathrm{a}$ & $331.2 \mathrm{a}$ & $352.5 \mathrm{a}$ & $364.4 \mathrm{ab}$ & $389.7 \mathrm{ab}$ & $400.3 \mathrm{a}$ & $414.0 \mathrm{a}$ \\
\hline IAC 13 & $377.9 \mathrm{ab}$ & $359.4 \mathrm{ab}$ & $343.2 \mathrm{abc}$ & $309.2 \mathrm{a}$ & $338.0 \mathrm{a}$ & $347.4 \mathrm{a}$ & $375.8 \mathrm{a}$ & $410.0 \mathrm{a}$ & $406.8 \mathrm{a}$ & $419.1 \mathrm{a}$ \\
\hline Fécula Branca & $398.4 \mathrm{a}$ & $386.6 \mathrm{a}$ & $364.4 \mathrm{ab}$ & $326.5 \mathrm{a}$ & $312.3 \mathrm{ab}$ & $351.1 \mathrm{a}$ & $360.6 \mathrm{ab}$ & $376.5 \mathrm{ab}$ & $371.4 \mathrm{a}$ & $389.8 \mathrm{ab}$ \\
\hline $\mathrm{F}$ & $5.60 *$ & $4.25^{*}$ & $8.19 *$ & $14.74 *$ & $17.13 *$ & $21.24 *$ & $12.87 *$ & $13.26 *$ & $11.55^{*}$ & $12.49 *$ \\
\hline
\end{tabular}

*Significant at a level of $5 \%$ probability by the $\mathrm{F}$ test $(\mathrm{P} \leq 0.05)$

$\mathrm{ns}=$ non-significant at a level of $5 \%$ probability by the $\mathrm{F}$ test $(\mathrm{P} \leq 0.05)$

Means followed by the same letter in the column did not differ by the Tukey test.

The reduction of starch content in the storage roots dry matter was due to the regeneration of vegetative structure of plants, which was possible both because of the pluvial precipitation increase, and the high registered temperatures (Fig. 1). However, a new starch accumulation phase began in the storage roots of all the cultivars. The highest values were reached at the end of the harvest, that is at 21 months, when the plants were again at vegetative rest.

Although the means of the starch contents in the storage roots dry matter correlated positively $(\mathrm{r}=$ $\left.0.78^{*}\right)$ with the storage roots dry matter content, such characteristics were not found to be directly related to a cause and effect condition.

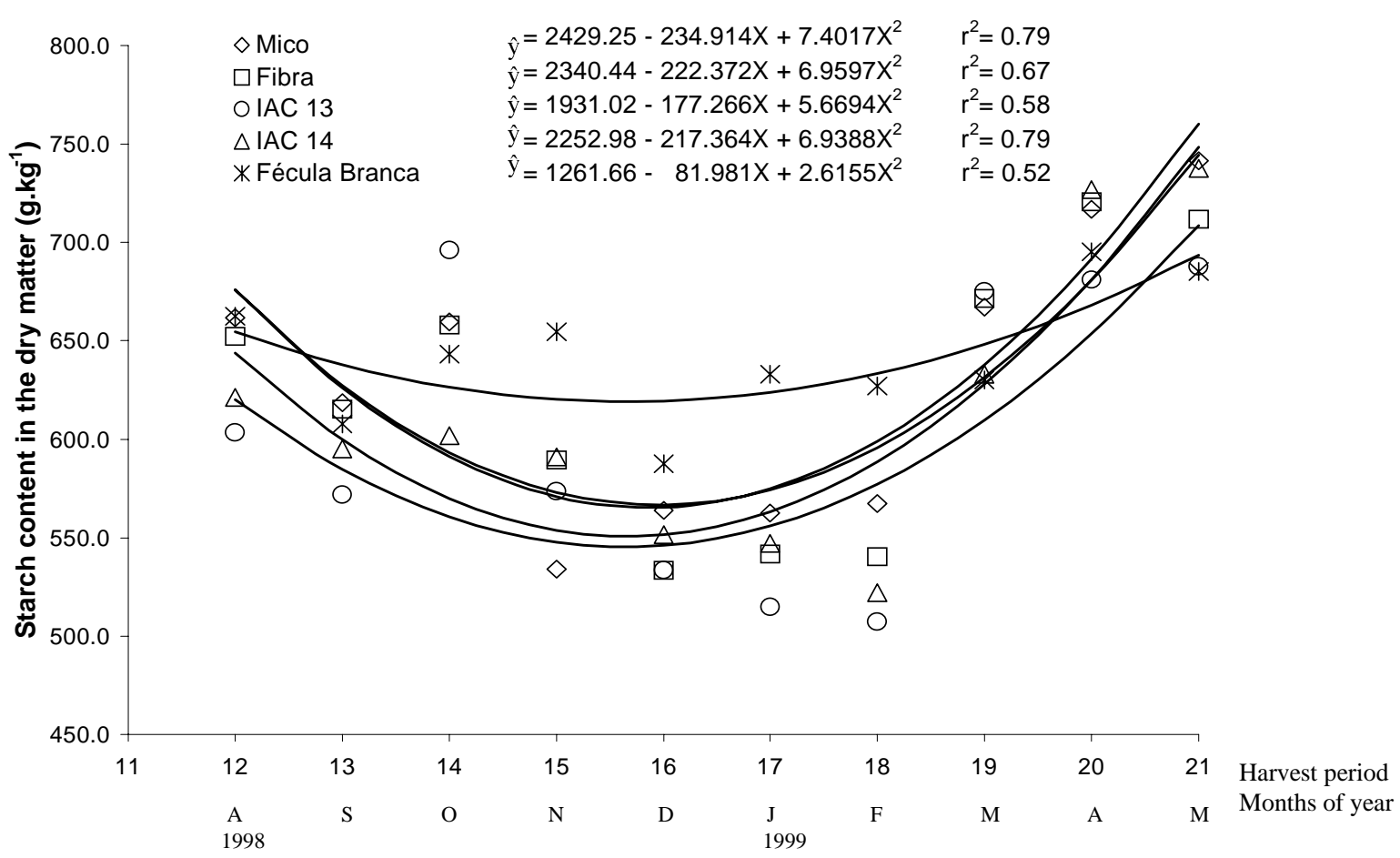

Figure 3 - Starch content based on the storage roots dry matter $\left(\mathrm{g} \cdot \mathrm{kg}^{-1}\right)$ of five cassava cultivars at 10 harvest times during the second plant cycle (Araruna-PR, 2001). 
Thus the reduction observed in the starch content based on the dry matter was not necessarily caused by a direct reduction in the dry matter content in the storage roots. Probably it was caused by the need to hydrolyze the starch stored in the storage roots to low weight carbohydrate molecules (Madore, 1994) to be used in the formation of new sprouts (Sales Filho, 1980).

The starch concentration in the storage roots dry matter was reduced by hydrolysis to soluble sugars, but this did not necessarily resulted in a reduction in the dry matter content. The reduction in the starch content, which occured concomitantly with the rise in sugar concentration in the cassava storage roots has been reported by Carvalho et al. (1993b).

The increase in starch content in the dry matter observed after 16 months might have occurred because the carbohydrate production rate by photosynthesis had supplanted the demand for those already stocked in the storage roots because of the regeneration of the photosynthesizing plant structure.

The starch content in the storage roots dry matter ranged from 507.19 to $741.48 \mathrm{~g} \cdot \mathrm{kg}^{-1}$. These values were lower than those reported by Sarmento (1997). However, there could be difficulties in making comparison among the data available in the literature, considering that in many cases, they were calculated by difference from the centesimal composition or using methods of low analytical precision.

Regarding the differences among the cultivars (Table 2), the Fécula Branca cultivar generally accounted for the highest starch contents present in the storage roots dry matter, although this cultivar did not differ significantly from the Mico, Fibra and IAC 14 cultivars at 12 months, or from the Mico, Fibra and IAC 13 cultivars at 14 months. No differences were observed among the cultivars at 13, 16 and 19 months of age. Differences among the cultivars for starch content in the dry matter were also reported by Sarmento (1997) who observed that the Mico cultivar was superior to Branca de Santa Catarina, Fibra and IAC 12 and speculated that this was a genetically controlled attribute.

Table 2 - Means of starch content based on the storage roots dry matter $\left(\mathrm{g}^{\mathrm{kg}} \mathrm{kg}^{-1}\right)$ of five cassava cultivars at 10 harvest times during the second plant cycle (Araruna-PR, 2001) (means of four replicates)

\begin{tabular}{|c|c|c|c|c|c|c|c|c|c|c|}
\hline \multirow{3}{*}{ Cultivars } & \multicolumn{10}{|c|}{ Starch content in the dry matter $\left(\mathrm{g} \cdot \mathrm{kg}^{-1}\right)$} \\
\hline & \multicolumn{10}{|c|}{ Harvest period } \\
\hline & 12 (Aug) & 13 (Sep) & $14(\mathrm{Oct})$ & 15 (Nov) & 16 (Dec) & 17 (Jan) & 18 (Feb) & 19 (Mar) & 20 (Apr) & 21 (May) \\
\hline Mico & $661.80 \mathrm{a}$ & $618.58 \mathrm{a}$ & $659.77 \mathrm{a}$ & $534.04 \mathrm{~b}$ & $563.92 \mathrm{a}$ & 562.62 b & $567.17 \mathrm{~b}$ & $667.26 \mathrm{a}$ & $717.00 \mathrm{a}$ & $741.48 \mathrm{a}$ \\
\hline Fibra & $652.21 \mathrm{ab}$ & $615.44 \mathrm{a}$ & $658.02 \mathrm{ab}$ & $589.35 \mathrm{~b}$ & $533.48 \mathrm{a}$ & $541.70 \mathrm{~b}$ & 540.57 bc & $671.53 \mathrm{a}$ & $720.76 \mathrm{a}$ & $711.94 \mathrm{a}$ \\
\hline IAC 14 & $621.49 \mathrm{ab}$ & $595.10 \mathrm{a}$ & $601.69 \mathrm{~b}$ & $591.03 \mathrm{~b}$ & $551.61 \mathrm{a}$ & $547.02 \mathrm{~b}$ & $521.96 \mathrm{bc}$ & $633.20 \mathrm{a}$ & $727.11 \mathrm{a}$ & $737.81 \mathrm{a}$ \\
\hline IAC 13 & $603.49 \mathrm{~b}$ & $571.76 \mathrm{a}$ & $625.96 \mathrm{ab}$ & $573.48 \mathrm{~b}$ & $533.53 \mathrm{a}$ & $514.89 \mathrm{~b}$ & 507.19 & $674.97 \mathrm{a}$ & $681.01 \mathrm{a}$ & $687.81 \mathrm{a}$ \\
\hline Fécula Branca & $662.36 \mathrm{a}$ & $607.75 \mathrm{a}$ & $643.31 \mathrm{ab}$ & $654.66 \mathrm{a}$ & $587.49 \mathrm{a}$ & $633.21 \mathrm{a}$ & $626.91 \mathrm{a}$ & $630.11 \mathrm{a}$ & $695.27 \mathrm{a}$ & $685.20 \mathrm{a}$ \\
\hline $\mathrm{F}$ & $3.18 *$ & $2.42^{\mathrm{ns}}$ & $2.68 *$ & $8.59 *$ & $2.34^{\text {ns }}$ & $8.97 *$ & $10.07 *$ & $2.18^{\mathrm{ns}}$ & $1.70^{\mathrm{ns}}$ & $3.22 *$ \\
\hline
\end{tabular}

*Significant at a level of $5 \%$ probability by the $\mathrm{F}$ test $(\mathrm{P} \leq 0.05)$

$\mathrm{ns}=$ non-significant at a level of $5 \%$ probability by the $\mathrm{F}$ test $(\mathrm{P} \leq 0.05)$

Means followed by the same letter in the column did not differ by the Tukey test.

The pattern of the starch content means based on the storage roots fresh matter observed in the harvest period enabled this characteristic to be adjusted to polynomial models of quadratic order for all the cultivars (Fig. 4). Generally, the fit of the curves obtained for this characteristic was better than that obtained for the starch content in dry matter curves, possibly because the starch content curve in storage roots fresh matter was obtained from the storage roots dry matter which influenced it very strongly.
Similar to the starch content in the dry matter, the starch content based on the storage roots fresh matter was high at the first harvest, but decreased to the minimum point at $15.38,15.78$ and 15.81 months of age for IAC 13, IAC 14 and Fibra, respectively, but occurred later at 16.21 and 16.20 months for Mico and Fécula Branca, respectively. The lowest content observed for Fécula Branca at 16.20 months was $210.31 \mathrm{~g} . \mathrm{kg}^{-1}$, i.e. $12.5,13.8$, 16.4 and $42.8 \%$ superior to the minimum values observed for IAC 14 (187.01 g.kg-1), IAC 13 (184.82 g. $\left.\mathrm{kg}^{-1}\right)$, Fibra (180.72 $\left.\mathrm{g} . \mathrm{kg}^{-1}\right)$ and Mico 
(147.28 g. $\left.\mathrm{kg}^{-1}\right)$, respectively. Within the assessment period, a new accumulation peak was recorded at the last harvest, which was carried out at 21 months of age.
The high starch content present in the storage roots fresh matter at 21 months of age occurred at the beginning of the second physiological rest period of the plants. In such a period, lower temperatures and low rainfall were recorded (Fig. 1) and this was the period when plants reached the highest starch contents in their storage roots (Andrade, 1989; Sriroth et al., 1999).

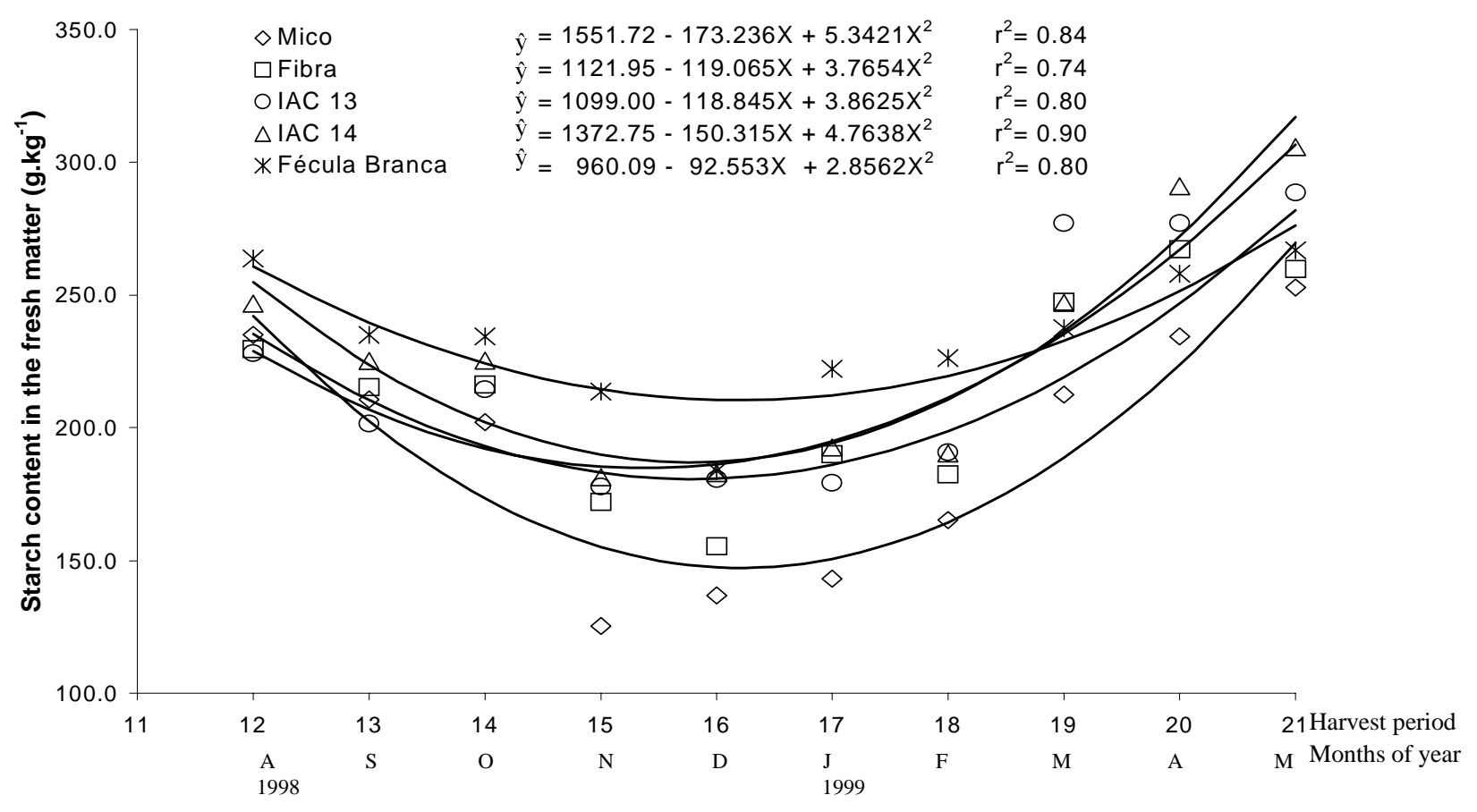

Figure 4 - Starch content on the storage roots fresh matter $\left(\mathrm{g} \cdot \mathrm{kg}^{-1}\right)$ of five cassava cultivars at 10 harvest times during the second plant cycle (Araruna-PR, 2001).

Table 3 - Means of starch content based on the storage roots fresh matter $\left(\mathrm{g}_{\mathrm{kg}} \mathrm{kg}^{-1}\right)$ of five cassava cultivars at 10 harvest times during the second plant cycle (Araruna-PR, 2001) (means of four replicates)

\section{Starch content in the fresh matter (g.kg $\left.{ }^{-1}\right)$}

\begin{tabular}{|c|c|c|c|c|c|c|c|c|c|c|}
\hline \multirow[t]{2}{*}{ Cultivars } & \multicolumn{10}{|c|}{ Harvest period } \\
\hline & 12 (Aug) & 13 (Sep) & $14($ Oct $)$ & 15 (Nov) & 16 (Dec) & 17 (Jan) & 18 (Feb) & 19 (Mar) & 20 (Apr) & 21 (May) \\
\hline Mico & $234.95 \mathrm{ab}$ & $210.63 \mathrm{ab}$ & $202.14 \mathrm{a}$ & $125.36 \mathrm{c}$ & $136.90 \mathrm{~b}$ & $143.04 \mathrm{c}$ & $165.27 \mathrm{~b}$ & $212.39 \mathrm{c}$ & $234.37 \mathrm{~b}$ & $252.79 \mathrm{c}$ \\
\hline Fibra & $229.71 \mathrm{~b}$ & $215.30 \mathrm{ab}$ & $216.32 \mathrm{a}$ & $172.00 \mathrm{~b}$ & $155.31 \mathrm{ab}$ & $190.06 \mathrm{ab}$ & $182.35 \mathrm{~b}$ & $247.55 a b$ & $267.24 \mathrm{ab}$ & $259.85 \mathrm{bc}$ \\
\hline IAC 14 & $246.71 \mathrm{ab}$ & $225.21 \mathrm{ab}$ & $225.23 \mathrm{a}$ & $181.36 \mathrm{ab}$ & $182.95 \mathrm{a}$ & $192.56 \mathrm{ab}$ & $190.25 \mathrm{~b}$ & $247.05 \mathrm{ab}$ & $291.12 \mathrm{a}$ & $305.64 \mathrm{a}$ \\
\hline IAC 13 & $227.98 \mathrm{~b}$ & $201.64 \mathrm{~b}$ & $214.51 \mathrm{a}$ & $177.87 \quad b$ & $180.65 \mathrm{a}$ & $179.16 \mathrm{~b}$ & $190.69 \mathrm{~b}$ & $277.07 \mathrm{a}$ & $277.00 \mathrm{a}$ & $288.51 \mathrm{ab}$ \\
\hline Fécula Branca & $263.75 \mathrm{a}$ & $235.03 \mathrm{a}$ & $234.35 \mathrm{a}$ & $213.64 \mathrm{a}$ & $183.79 \mathrm{a}$ & $222.24 \mathrm{a}$ & $226.22 \mathrm{a}$ & $237.51 \mathrm{bc}$ & $258.12 \mathrm{ab}$ & $266.80 \mathrm{bc}$ \\
\hline $\mathrm{F}$ & $3.08^{*}$ & $2.33^{\text {ns }}$ & $2.04^{\mathrm{ns}}$ & $13.97 *$ & $6.13^{*}$ & $11.37 *$ & $6.84^{*}$ & $7.51^{*}$ & $6.32 *$ & $6.65^{*}$ \\
\hline
\end{tabular}

*Significant at a level of 5\% probability by the $\mathrm{F}$ test $(\mathrm{P} \leq 0.05)$

$\mathrm{ns}=$ non-significant at a level of $5 \%$ probability by the $\mathrm{F}$ test $(\mathrm{P} \leq 0.05)$

Means followed by the same letter in the column did not differ by the Tukey test. 
Thus, the fact that the plant was conditioned to the climate for the maximum starch accumulation in the storage roots might result in starch accumulation peaks at various ages, as reported by Wholey and Booth (1979) at 15 months, Kayode (1983) at 12 and 15 months, Andrade (1989) at 9 months, Carvalho et al. (1993b) at 20 months and by Sriroth et al. (1999) at 14 months.

The average starch content in the storage roots fresh matter ranged from $167.92 \mathrm{~g} \cdot \mathrm{kg}^{-1}$ at 16 months to $274.71 \mathrm{~g} . \mathrm{kg}^{-1}$ at 21 months. In general, these values were lower to those related by Carvalho et al. (1993b). However, they were similar to those obtained by Sriroth et al. (1999) and Kayode (1983).

Regarding the cultivars (Table 3) only at 14 months, corresponding to the third harvest time, no differences were detected among the cultivars assessed.

At the other harvest times, the cultivars behaved differently for starch content present in the storage roots fresh matter. In the first harvest, carried out at 12 months of age, the Fécula Branca cultivar had the highest content but this was not different from IAC 14 and Mico.
The data were similar to those obtained by Vidigal Filho et al. (2000) in plants with one vegetative cycle. Higher dry matter content was found in Fécula Branca, IAC 14, IAC 13 and IAC 12 cultivars and lower the Mico cultivar. In the present study, similar behavior was also observed at 13 months, but this was the month when the Fibra cultivar also presented high values. The Fécula Branca cultivar also showed the highest values from 15 to 18 months, but did not differ from IAC 14 at 15 months, from IAC 14, IAC 13 and Fibra at 16 months from IAC 14 and Fibra at 17 months. At 18 months, Fécula Branca surpassed the other cultivars but was inferior to IAC 13, Fibra and IAC 14 at 19 months, but did not differ from these cultivars at 20 months. At the last harvest, at 21 months, the IAC 14 and IAC 13 cultivars showed the highest means. Furthermore, except for the first three harvests, the Mico cultivar tended to present the lowest mean, a fact which reinforces the data obtained by Vidigal Filho et al. (2000).

Data obtained for crude leaf protein content allowed fitting of linear models for all the cultivars.

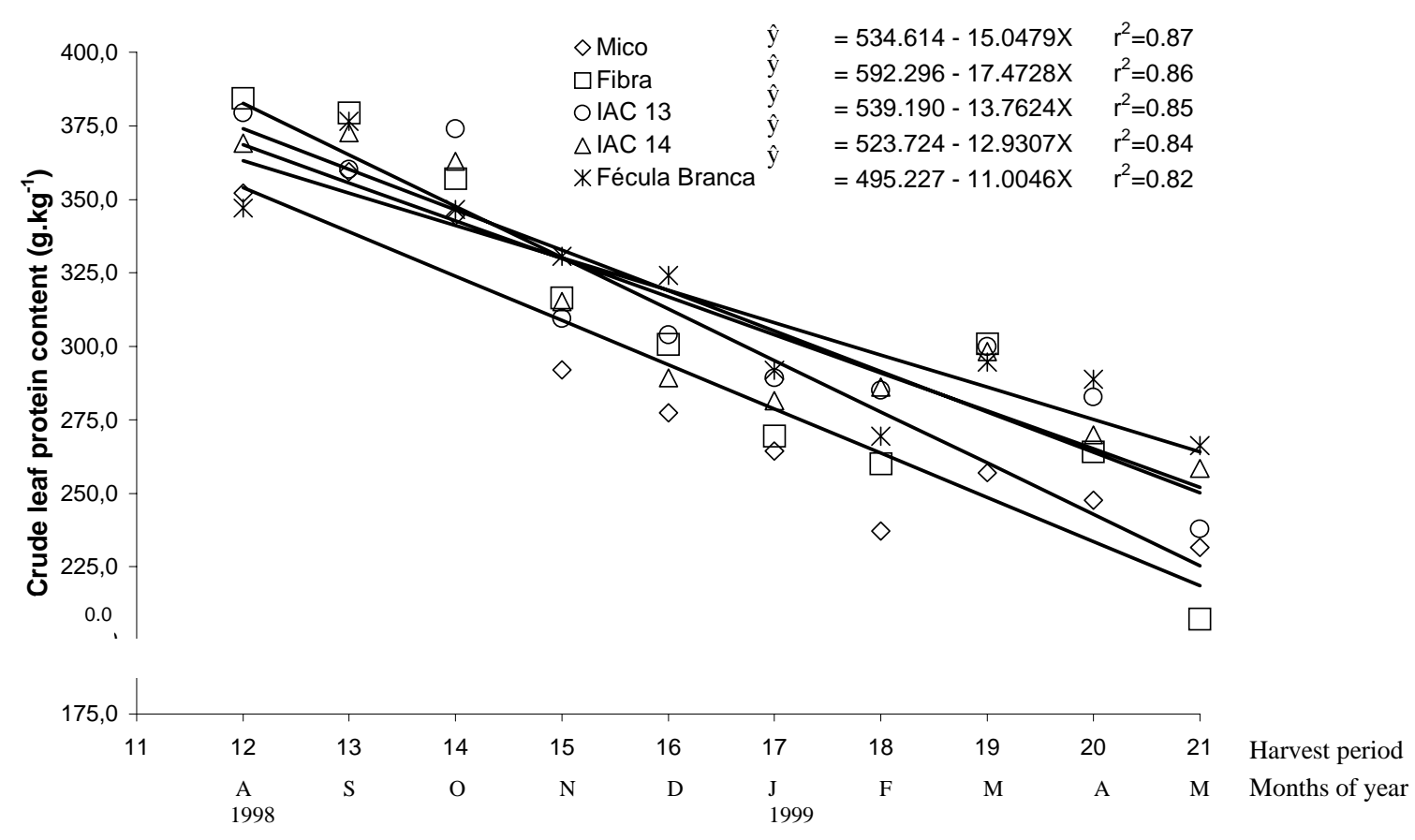

Figure 5 - Crude leaf protein content (g.kg-1) of five cassava cultivars at 10 harvest times during the second plant cycle (Araruna-PR, 2001). 
The highest crude protein contents occurred at the first harvest, which was carried out at 12 months of age. From this period onwards, a continuous decrease in the contents was recorded until the last harvest (Fig. 5) when the lowest means were observed, which were equivalent on average to $66 \%$ of the value obtained in the first harvest. The variation in the protein contents in the cassava canopy because of the plant age was also observed by Carvalho et al. (1985) who found higher protein contents when the harvests were carried out at 12 and 16 months. Similarly, Carvalho et al. (1991) obtained higher protein values at 12 and 16 months after planting, which corresponded to the period of highest leafing in the plants.

The authors found the lowest means at 8 and 20 months, which corresponded to July, when the plants had few leaves. Carvalho et al. (1993a) studied three cassava cultivars harvested at 11 and 18 months of age and obtained the highest protein contents in the first harvest periods, with minimum values occurring from 15 to 17 months, and there was a slight increase in the mean at the last harvest. However, it is possible that the authors mentioned protein content increase because of they did not use a mathematical model to fit the data obtained, which could express more precisely the dynamic of the crude protein contents in the different assessment periods. The crude protein content obtained in the present study varied on average from 366.38 g.kg ${ }^{-1}$ to 240.36 g.kg ${ }^{-1}$ and was therefore on average $34.89 \%$ superior to those observed by Carvalho et al. (1993a) during the second plant cycle. However, the results obtained by Carvalho et al. (1993a) at the last harvest period were practically identical to those obtained in the present study (at 21 months of age). The variation interval in the crude protein contents in cassava leaves found in the present study was compatible with that presented by Ravindran (1993) who stated that although the mean protein contents in cassava leaves were around 210.00 g. $\mathrm{kg}^{-1}$ they could vary from $147 \mathrm{~g} . \mathrm{kg}^{-1}$ to 400 g. $\mathrm{kg}^{-1}$. The last harvests, carried out at the phase of least leaf protein content corresponded to the period of greatest starch accumulation in the storage roots (Figs. 3 and 4).

Table 4 - Means of crude leaf protein content $\left(\mathrm{g} \cdot \mathrm{kg}^{-1}\right)$ of five cassava cultivars at 10 harvest times during the second plant cycle. (Araruna-PR, 2001) (means of four replicates)

Crude leaf protein content $\left({\left.\mathrm{g} . \mathrm{kg}^{-1}\right)}^{-1}\right.$

\begin{tabular}{|c|c|c|c|c|c|c|c|c|c|c|}
\hline \multirow[t]{2}{*}{ Cultivars } & \multicolumn{10}{|c|}{ Harvest period } \\
\hline & 12 (Aug) & 13 (Sep) & 14 (Oct) & 15 (Nov) & 16 (Dec) & 17 (Jan) & 18 (Feb) & 19 (Mar) & 20 (Apr) & 21 (May) \\
\hline Mico & $352.1 \mathrm{~b}$ & $359.5 \mathrm{a}$ & $344.4 \quad \mathrm{~b}$ & $292.1 \quad b$ & $277.4 \quad c$ & $264.4 \quad \mathrm{~b}$ & $237.2 \quad \mathrm{c}$ & $257.0 \mathrm{~b}$ & $247.6 \quad c$ & $231.6 \quad \mathrm{c}$ \\
\hline Fibra & $384.4 \mathrm{a}$ & $379.4 \mathrm{a}$ & $357.1 \mathrm{ab}$ & $316.6 \mathrm{a}$ & $300.7 \mathrm{abc}$ & $269.5 \mathrm{ab}$ & $260.1 \mathrm{bc}$ & $300.8 \mathrm{a}$ & $264.1 \mathrm{bc}$ & 207.3 \\
\hline IAC 14 & $369.1 \mathrm{ab}$ & $372.7 \mathrm{a}$ & $363.0 \mathrm{ab}$ & $315.2 \mathrm{ab}$ & $289.3 \mathrm{bc}$ & $281.5 \mathrm{ab}$ & $286.2 \mathrm{a}$ & $298.2 \mathrm{a}$ & $269.9 \mathrm{abc}$ & $258.6 \mathrm{ab}$ \\
\hline IAC 13 & $379.3 \mathrm{a}$ & $360.0 \mathrm{a}$ & $373.9 \mathrm{a}$ & $309.4 \mathrm{ab}$ & $303.8 \mathrm{ab}$ & $289.3 \mathrm{a}$ & $284.9 \mathrm{a}$ & 299.9 a & $282.7 \mathrm{ab}$ & $238.0 \mathrm{bc}$ \\
\hline Fécula Branca & $347.0 \mathrm{~b}$ & $376.6 \mathrm{a}$ & $346.7 \quad b$ & $330.7 \mathrm{a}$ & $324.2 \mathrm{a}$ & $292.0 \mathrm{a}$ & $269.5 \mathrm{ab}$ & $294.7 \mathrm{a}$ & $288.9 \mathrm{a}$ & $266.3 \mathrm{a}$ \\
\hline $\mathrm{F}$ & $7.19^{*}$ & $2.31^{\mathrm{ns}}$ & $3.91 *$ & $5.19 *$ & $8.15^{*}$ & $3.89 *$ & $10.86^{*}$ & $9.29 *$ & $7.01 *$ & $14.50^{*}$ \\
\hline
\end{tabular}

*Significant at a level of $5 \%$ probability by the $\mathrm{F}$ test $(\mathrm{P} \leq 0.05)$

$\mathrm{ns}=$ non-significant at a level of $5 \%$ probability by the $\mathrm{F}$ test $(\mathrm{P} \leq 0.05)$

Means followed by the same letter in the column did not differ by the Tukey test.

Studies developed by Carvalho et al. (1985) and Carvalho et al. (1991) also showed an inverse relationship between crude leaf protein content and the starch content, but the results obtained by these authors refer to the starch content in the plant stems.

A possible explanation for the contrast in curves obtained in the present study could be due to a lower offer of carbohydrates for protein synthesis in the last harvest, because of the higher accumulation of these carbohydrates in the storage roots (Figs. 3 and 4). According to Holmes and
Wilson (1979), there was an increase in demand for carbohydrates in the storage root development periods, making the plant direct the metabolism for its synthesis and for accumulation in the storage roots in the form of starch, in detriment to protein synthesis.

Except for the harvest at 13 months of age, all the other cultivar assessments (Table 4) resulted in significantly different means $(\mathrm{P} \leq 0.05)$. In general, IAC 13 and IAC 14 cultivars had higher means over the harvest periods but did not differ from Fibra at 12, 14, 15, 1617 and 19 months or from 
Fécula Branca at 14, 16, 17, 18, 19, 20 and 21 months of age. However, IAC 14 was inferior to Fibra, IAC 13 and Fécula Branca at 16 months, while IAC 13 had lower values than IAC 14 and Fécula Branca at 21 months of age. The Mico cultivar tended to present the lowest means.

\section{ACKNOWLEDGEMENTS}

The authors thank Capes and Pinduca Indústria Alimentícia Ltda for funding the project.

\section{RESUMO}

Com o objetivo de determinar o efeito de épocas de colheita na qualidade das raízes tuberosas e parte aérea de cultivares de mandioca, instalou-se um experimento delineado em blocos completos casualizados, em parcelas subdivididas, com quatro repetições, estando nas parcelas, cinco cultivares e, nas subparcelas, dez épocas de colheita. A cultivar IAC 13 apresentou maior taxa de acúmulo de massa seca nas raízes tuberosas, enquanto a Mico, a menor taxa. O período de menores teores de massa seca nas raízes tuberosas ocorreu mais tardiamente para Fécula Branca, Mico e IAC 14, sendo que os teores mínimos de amido na massa fresca das raízes tuberosas, foram mais tardios para Fécula Branca e Mico. Em geral, IAC 14, IAC 13 e Fécula Branca apresentaram maiores teores de massa seca nas raízes tuberosas, enquanto que maiores teores de amido na massa seca e na massa fresca foram obtidos por Fécula Branca. O teor de proteína bruta nas folhas decresceu com a idade das plantas.

\section{REFERENCES}

Andrade, C. A. B. (1989), Efeitos de espaçamentos, idades de colheita e anos de plantio sobre algumas características de duas cultivares de mandioca (Manihot esculenta, Crantz). Master's thesis. Escola Superior de Agricultura de Lavras, Lavras - MG, Brasil.

Association of Official Analytical Chemists, Washington. (1970), Official methods of analysis of the AOAC. 11. ed. Washington.

Balagopalan, C.; Padmaja, G.; Nanda, S. K. and Moorthy, S. N. (1988), Cassava in food, feed, and industry. Florida : C. R.C.Press.
Banzatto, D. A. and Kronka, S. N. (1995), Experimentação Agrícola. 3. ed. Jaboticabal : FUNEP.

Carvalho, V. D.; Paula, M. B. and Juste Jr., E. S. G. (1985), Efeito da época de colheita no rendimento e composição química de fenos de parte aérea de dez cultivares de mandioca. Revista Brasileira de Mandioca, 4, 43-59.

Carvalho, V. D.; Chagas, S. J. R. and Juste Jr., E. S. G. (1991), Influência da idade na colheita sobre a produtividade e valor nutritivo da parte aérea de seis cultivares de mandioca. Revista Brasileira de Mandioca, 10, 47-58.

Carvalho, V. D.; Chagas, S. J. R.; Botrel, N. and Juste Jr., E. S. G. (1993a), Teores de proteína na parte aérea de cultivares de mandioca em diferentes épocas de colheita. Revista Brasileira de Mandioca, 12, 13-20.

Carvalho, V. D.; Chagas, S. J. R. and Botrel, N. (1993b), Produtividade e qualidade de raízes em diferentes épocas de colheita de variedades de mandioca. Revista Brasileira de Mandioca, 12, 49-58.

Cassava. (2000), A mother crop for millions. Disponível em http://www.bath.ac.uk/admin/topics/ topics22/cassava.htm. Acesso em 5 de abril.

Diniz, S. P. S. S. (1999), Aspectos fisiológicos e bioquímicos do ácido fusárico, seus efeitos sobre o tecido vegetal, bem como a ação do bálsamo de copaíba no controle da população do Fusarium sp. Doctoral thesis. Universidade Estadual Paulista, Botucatu - SP.

Doreto, M. (1993), Distribuição da cultura da mandioca no Paraná nos anos 80. Iapar, (Informe de Pesquisa, 102), Londrina.

Embrapa. (1999), Sistema brasileiro de classificação de solo. Rio de Janeiro : CNPS.

El-Sharkawy, M. A.; Cock, J. H. and Cadena, G. (1984), Influence of differences in leaf anatomy on net photosynthetic rates oh some cultivars of cassava. Photosynthesis Research., 5, 235-242.

Fukuda, W. M. G. and Borges, M. F. (1990), Influência da idade de colheita sobre a qualidade de raízes em diferentes cultivares de mandioca de mesa. Revista Brasileira de Mandioca, 9, 7-19.

Godoy, H.; Correia, A. R. and Santos, D. (1976), Clima do Paraná: manual agropecuário para o Paraná. Londrina : IAPAR.

Hammer, G. L.; Hobman, F. R. and Shepherd, R. K. (1987), Effects of planting time and harvest age on cassava (Manihot esculenta) in Northern Australia. I. Crop growth and yield in moist environments. Experimental Agriculture, 23, 401-414.

Hobman, F. R.; Hammer, G. L. and Shepherd, R. K. (1987), Effects of planting time and harvest age on cassava (Manihot esculenta) in Northern Australia. II. Crop growth and yield in a seasonally-dry environment. Experimental Agriculture, 23, 415-424. 
Holmes, E. B. and Wilson, L. A. (1979), Effects of nitrogen supply on early growth and development and nitrate reductase activity in two cassava cultivars. Paper presented at the Proceedings of the $5^{\text {th }}$ Symposium of the International Society for Tropical Root Crops. Manilla.

Jesus, V. S.; Moraes, C. F.; Teles, F. F. F. and Sediyama, C. S. (1986), Teor de carboidrato em raízes e caules de dez variedades de mandioca (Manihot esculenta, Crantz), durante o primeiro ciclo. Revista Brasileira de Mandioca, 5, 91-98.

Kayode, G. O. (1983), Effects of various planting and harvesting times on the yield, HCN, dry-matter accumulation and starch content of four cassava varieties in a tropical rainforest region. Journal of Agricultural Science, 101, 633-636.

Keating, B. A.; Evenson, J. P. and Fukai, S. (1982), Environmental effects on growth and development of cassava (Manihot esculenta, Crantz). III. Assimilate distribution and storage organ yield. Field Crops Research, 5, 293-303.

Madore, M. A. (1994), Phloem transport of solutes in crop plants. In: Handbook of plant and crop physiology, ed. M. Pessorakli. The University of Arizona, Tucson, Arizona. pp. 337-353.

Ravindran, V. (1993), Cassava leaves as animal feed: potential and limitations. Journal of the Science of Food and Agriculture, 61, 141-150.

Sales Filho, J. B. (1980), Distribuição de carboidratos em plantas de mandioca (Manihot esculenta, Crantz) e o efeito do teor de reservas, na brotação e enraizamento de estacas de três posições do caule. Master's thesis. Universidade Federal de Viçosa, Viçosa-MG, Brasil.

Sarmento, S. B. S. (1997), Caracterização da fécula de mandioca (Manihot esculenta, Crantz) no período de colheita de cultivares de uso industrial. Doctoral thesis. Universidade de São Paulo, São Paulo - SP, Brasil.

Silva, D. J. (1981), Análise de alimentos: métodos químicos e biológicos. Universidade Federal de Viçosa, Viçosa.

Sriroth, K.; Santisopasri, V.; Petchalanuwat, C.; Kurotjana-Wong, K.; Piyachomkwan, K. and Oates, C. G. (1999), Cassava starch granule structurefunction properties: influence of time and conditions at harvest on four cultivars of cassava starch. Carbohydrates Polymers, 38, 161-170.

Veltkamp, H. J. (1985), Physiological causes of yield variation in cassava (Manihot esculenta, Crantz). Wageningen. Ph.D. thesis, Netherlands Agric. Univ., Netherlands.

Vidigal Filho, P. S.; Pequeno, M. G.; Scapim, C. A.; Gonçalves-Vidigal, M. C.; Maia, R. R.; Sagrilo, E.; Simon, G. A. and Lima, R. S. (2000), Avaliação de cultivares de mandioca na região Noroeste do Paraná. Bragantia, 59, 69-75.
Wholey, D. W. and Booth, R. H. (1979), Influence of variety and planting density on starch accumulation in cassava roots. Journal of the Science of Food and Agriculture, 30, 165-170.

Received: July 31, 2001; Revised: February 19, 2002; Accepted: July 03, 2002. 